\title{
Amino Acid Composition of Kilishi - Nigerian (Beef Jerky) Meat
}

\author{
Emmanuel Ilesanmi Adeyeye ${ }^{* 1}$, Olatunde Abass Oseni ${ }^{2}$, \\ Kayode Olugbenga Popoola ${ }^{1}$, Yusuff Ayinde Gbolagade ${ }^{3}$, \\ Abioye Rauf Olatoye ${ }^{1}$, Kolade Idowu ${ }^{1}$ \\ ${ }^{1}$ Department of Chemistry (Analytical Unit), Ekiti State University, PMB 5363, \\ Ado - Ekiti, Nigeria
}

${ }^{2}$ Department of Medical Biochemistry, College of Medicine, Ekiti State University, PMB 5363, Ado - Ekiti, Nigeria

${ }^{3}$ Central Laboratory, Ekiti State University, PMB 5363, Ado - Ekiti, Nigeria

*Corresponding author: eiadeyeye@yahoo.com, adeyeyeilesanmi2012@gmail.com

Keywords: Amino acid composition; Nigerian, Kilishi meat

\begin{abstract}
The article reports the amino acid composition of Nigerian beef jerky meat called Kilishi. Kilishi is consumed dry, hence determination was on dry weight basis. Sample was purchased in Ado-Ekiti, Nigeria. Amino acid values were highest for non-essential amino acid in Glu

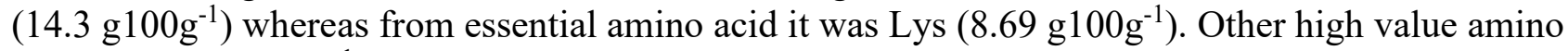
acids were (in g100g ${ }^{-1}$ ): Asp (8.85), Leu (7.68), Arg (6.02), Ile (4.08), Trp (1.02), Cys (1.18) and His (2.40). P-PER $1,2,3$ values were superior at values of $2.52-2.70$. EAAI $_{1}$ (soybean standard) was 1.23 and $\mathrm{EAAI}_{2}$ (egg standard) was 94.5 with corresponding BV of 91.3. Lys/Trp was very high at 8.55 and Met/Trp was 2.38. Values of TNEAA was $52.1 \mathrm{~g} 100 \mathrm{~g}^{-1}(57.7 \%)$ and TEAA was

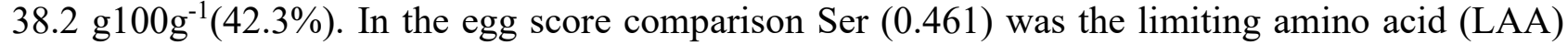
with protein corrected digestibility value of 0.338 ; in provisional EAA scoring pattern, LAA was Val (0.882) and corrected version was 0.742 ; in pre-school children requirement, LAA was Trp (0.927) and corrected value of 0.780 . Variation percentage values between the scores/corrected scores were virtually $12.2 \%$ per parameter compared. Correlation values between each score standard/corrected score values were significantly different at $r=0.01$ with values of $0.9997-0.99999$. Estimates of amino acid requirements at ages $10-12$ years $\left(\mathrm{mg} \mathrm{kg}^{-1} \mathrm{day}^{-1}\right)$ showed kilishi to be better than the standards at $74.9 \%-453 \%$. Results showed that kiishi is protein-condensed.
\end{abstract}

\section{Introduction}

Kilishi is a version of jerky meat that originated in Hausaland (in Nigeria). It is a derived form of suya, made from deboned cow, sheep or goat meat. Each of the selected muscle is sliced into sheets of one metre or less for easy drying. The dried sheets of meat are then collected and kept for the next process [1]. [Jerky is lean trimmed meat that has been cut into strips and dreid (dehydrated) to prevent spoilage]. Normally, this drying includes the addition of salt to prevent bacteria growth before the meat has finished the dehydrating process [2].

A paste made from peanuts, called labu, is diluted with enough water, spices, salt, ground onions, and sometimes sweetners such as honey, to add sweetness. A more natural way to add sweetness is by adding date palm. The dried "sheets" of meat are then immersed one by one in the labu paste to coat them, and then left for hours before roasting to taste $[3,4]$.

After roasting, the final moisture content ranged between $10-12 \%$, which decreases during storage at room temperature to $7 \%$. When packaged in hemetically sealed low density plastic pack of $0.038 \mathrm{~mm}$ thickness, kilishi remains appreciably stable at room temperature for a period of about one year [2].

Other ingredients or treatments to improve the quality of kilishi are: use of suya spice (suya pepper); cloves of garlic; one teaspoon of cloves (kanafuru); piece of ginger; stock cube; dry cayenne pepper seeds; the meat used for kilishi should be free from fat and should be gotten from the reddish part of the beef. Each of these items give kilishi special characteristics such as aroma, e.t.c. [5]. 
The above gave some information on the preparation, food characteristics and ingredients that improve the nutritional quality of kilishi. However, there is paucity of information on the amino acid composition and the digestibility of kilishi. These are the major concern of this work and in addition the nutritional importance of consuming kilishi will be discussed.

\section{Materials and Methods}

\section{Collection of samples}

Samples of packaged kilishi were purchased from a supermarket in Ado - Ekiti, Ekiti Sate, Nigeria. The Kilishi samples were actually prepared for sale by Golden Datol Ent., Akure, Ondo State, Nigeria. The kilishi sample was labelled to contain beef, onion, garlic, salt, honey, ginger, maggi, groundnut, pepper.

\section{Sample treatment}

The kilishi pack were further oven-dried, allowed to cool, blended and packaged in plastic containers and kept in a cool place pending analysis.

\section{Extraction and analysis}

Extraction and instrumental analysis were carried out by following AOAC method [6] and Danka et al. [7].

The dried pulverized sample was made to be free of water by ensuring constant weight for a period of time in the laboratory. The sample of $10.0 \mathrm{~g}$ was weighed into the $250 \mathrm{ml}$ conical flask capacity. The sample was defatted by extracting the fat content of the sample with $30 \mathrm{ml}$ of petroleum spirit three times with Soxhlet extractor that was equipped with thimble. The sample was hydrolyzed three times for complete hydrolysis to be achieved for the totality of amino acids recovery.

The pulverized and defatted sample was soaked with $30 \mathrm{ml}$ of $1 \mathrm{M}$ potassium hydroxide solution and was incubated for 48 hours at $110^{\circ} \mathrm{C}$ in hermetically closed borosilicate glass container. After the alkaline hydrolysis, the hydrolysate was neutralized to get $\mathrm{pH}$ in the range of 2.5-5.0. The solution was purified by cation-exchange solid-phase extraction. The amino acids in purified solutions were derivatised with ethylchloroformate by the established mechanism:

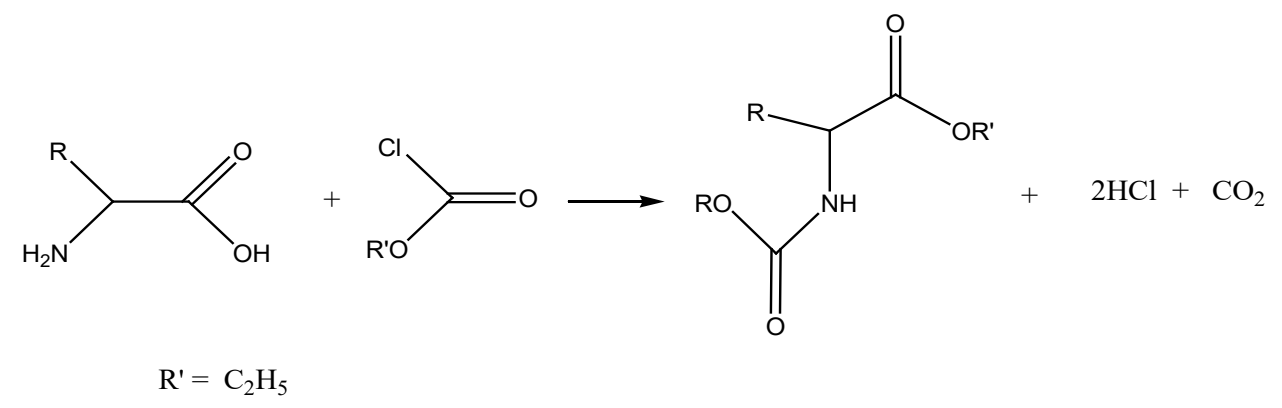

Figure 1. Derivatization process of amino acid

The derivatising reagent was removed by scavenging with nitrogen. The derivatized amino acid was made up to $1 \mathrm{ml}$ in a vial for gas chromatography analysis. The gas chromatographic conditions for the amino acids analysis were as follows: GC: HP6890 powered with HP ChemStation rev. A09.01 [1206] software; injection temperature: split injection; split ratio: 20:1; carrier gas: hydrogen; flow rate: $1.0 \mathrm{ml} \mathrm{min}^{-1}$; inlet temperature: $250^{\circ} \mathrm{C}$; column type: EZ; column dimensions: $10 \mathrm{~m} \times 0.2 \mathrm{~mm} \times 0.25 \mu \mathrm{m}$; oven programme: initial @ $110^{\circ} \mathrm{C}$, first ramp @ $27^{0} \mathrm{C} \mathrm{min}^{-1}$ to $320^{0} \mathrm{C}$; second, constant for $5 \mathrm{mins}$ at $320^{\circ} \mathrm{C}$; detector: PFPD; detector temperature: $320^{\circ} \mathrm{C}$; hydrogen pressure: 20 psi; compressed air: 35 psi.

Some calculations were made from the analytical data results.

(i) Estimation of isoelectric point $(p I)$ : The estimation of isoelectric point $(p I)$ for a mixture of amino acids was carried out using the equation of the form [8]: 


$$
\operatorname{IPm}=\sum_{i=1}^{n_{i}} I_{i} P_{i} X_{i}
$$

where IPm is the isoelectric point of the mixture of amino acids, IiPi is the isoelectric point of the $\mathrm{i}^{\text {th }}$ amino acid in the mixture and $\mathrm{Xi}$ is the mass or mole fraction of the $\mathrm{i}^{\text {th }}$ amino acid in the mixture.

(ii) Estimation of predicted protein efficiency ratio (P-PER): Computation of protein efficiency ratio (C-PER or P-PER) was done using the equations suggested by Almeyer et al. [9]:

$$
\begin{gathered}
\text { P-PER }_{1}=-0.468+0.454(\text { Leu })-0.105(\text { Tyr }) \\
\text { P-PER }_{2}=-0.684+0.456(\text { Leu })-0.047(\text { Pro }) \\
\text { P-PER }_{3}=-1.816+0.435 \times \text { Met }+0.78 \times \text { Leu }+0.211 \\
\text { x His }-0.944 \text { x Tyr }
\end{gathered}
$$

(iii) Leucine/isoleucine ratio: The leucine/isoleucine ratio, their differences and their percentage differences were calculated.

(iv) Determination of essential amino acid index (EAAI $\left.\mathbf{I}_{2}\right)$ : The method of EAAI calculation was due to Oser [10] using the egg protein amino acids as the standard.

(v) Calculation of biological value (BV): Computation of biological value (BV) was calculated following the equation of Oser [10]:

$$
\text { Biological value }=1.09(\text { EAAI })-11.73
$$

(vi) Computation of Lys/Trp and Met/Trp: The ratios of Lys/Trp (L/T) and Met/Trp (M/T) were computed.

(vii) Computation of amino acid scores: The amino acid scores were computed using three different procedures:

- Scores based on amino acid values compared with whole hen's egg amino acid profile [11].

- Scores based on essential amino acid scoring pattern [12].

- Scores based on essential amino acid suggested pattern of requirements for pre-school children [13].

(viii) Estimation of essential amino acid index (EAAI 1 ): The essential amino acid index was calculated by using the ratio of test protein to the reference protein for each eight essential amino acids plus histidine in the equation 6 [14]:

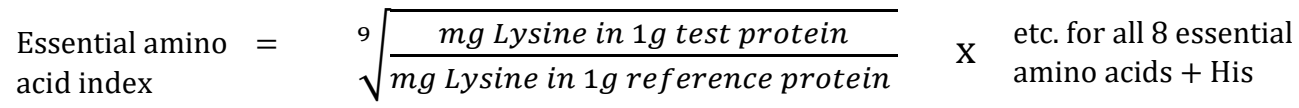

(ix) Estimates of amino acid requirements at different ages (mg $\mathrm{kg}^{-1} \mathrm{day}^{-1}$ ): These estimates were based on the essential amino requirements in $\mathrm{mg} \mathrm{kg}^{-1}$ day $^{-1}$ body weight of 10 - 12 years school boys [13]. The proposed formula for this calculation could be any of these two:

- Essential amino acid x 1000/100 x protein $\left(\mathrm{g} 100 \mathrm{~g}^{-1}\right)$

- Essential amino acid x $10 \mathrm{x}$ appropriate corresponding protein

(x) Other calculations: Other determinations such as total amino acid (TAA), total essential amino acid (TEAA), total non-essential amino acid (TNEAA), total acidic amino acid 
(TAAA), total basic amino acid (TBAA), total essential aliphatic amino acid (TEAlAA), e.t.c. and their percentages were made. Total sulphur amino acid (TSAA), percentage of cystine in TSAA (\% Cys in TSAA) were also calculated. The various amino acid groups into classes I-VII [15] were also calculated.

\section{Determination of Protein Digestibility}

The in-vitro protein digestibility was determined by the modified method of Akeson and Stahmant [16] and AOAC [6]. The sample containing the exact amount of $100 \mathrm{mg}$ of protein was incubated with $1.5 \mathrm{mg}$ of pepsin in $15 \mathrm{ml}$ of $0.1 \mathrm{M}$ hydrochloric acid at a temperature of $38^{\circ} \mathrm{C}$ for 3 hours. The solution was neutralized with $0.2 \mathrm{M}$ sodium hydroxide. Four $\mathrm{mg}(4 \mathrm{mg})$ of pancreas in $7.5 \mathrm{ml}$ phosphate buffer of $\mathrm{pH} 8.0$ was added with the addition of $1 \mathrm{ml}$ of toluene for the prevention of microbial growth and the solution was incubated for another 24 hours at $38^{\circ} \mathrm{C}$. The protein content in the solution after $24 \mathrm{~h}$ of digestion was taken as a measure of the digested product. Following the $24 \mathrm{~h}$ incubation, the enzyme was inactivated by the addition of $10 \mathrm{ml}$ of $10 \%$ trichloroacetic acid (TCA) to precipitate undigested protein that was later filtered off. The volume of the filterate was made up to $100 \mathrm{ml}$ and centrifuged at $5000 \mathrm{rpm}$ for 30 minutes; the supernatant was collected for protein determination. Blank was digested following the same procedure and employed $1 \mathrm{~g}$ of each source of enzyme to make protein measurement carried out effectively [17]. The digestibility of the protein was calculated by the equation below:

$$
\text { Digestibility }=\frac{\text { Protein in supernant }}{\text { Total protein of the sample }} \times 100
$$

\section{Determination of Protein Digestibility-Corrected Amino Acid Score}

To calculate for protein digestibility-corrected amino acid score for individual foods requires some steps to be taken. These steps are enumerated as follows. Proximate composition must be determined; protein can then be calculated by using a nitrogen-to-protein conversion factor of 6.25. In amino acid profile, protein hydrolysate should be prepared and analysed for amino acid using standard method. Amino acid scores would then be calculated (to give uncorrected amino acid scores). Based on the determined protein digestibility, protein digestibility-corrected amino acid score (PDCAAS) of the test food was then calculated by multiplying the amino acid score $\mathrm{x}$ true protein digestibility (or each amino acid score might also be corrected using this similar approach as the case may be). In this report, the score was expressed as a decimal, but it can be expressed in percentage terms [18].

\section{Statistical Evaluation}

Data results in Tables 1, 5, 6 and 7 were subjected to statistical analyses of correlation coefficient $\left(r_{x y}\right)$, regression coefficient $(R x y)$, coefficient of determination or variance $\left(r_{x y}{ }^{2}\right)$, the coefficient of alienation $\left(\mathrm{C}_{\mathrm{A}}\right)$ and index of forecasting efficiency (IFE). Other calculations were grand mean, standard deviation (SD) and coefficient of variation (CV\%). The $r_{x y}$ value was converted to critical Table value $\left(\mathrm{r}_{\mathrm{T}}\right)$ to see if significant differences existed among the various comparisons made in the Tables enumerated above at $\mathrm{r}=0.01$ [19].

\section{Results and Discussion}

Amino acids encountered in this work:

Lysine (Lys) [PubChem C6H14N202, CID: 5962]; Glutamic acid (Glu) [PubChem C5H9NO4, CID: 33032]; Methionine (Met) [PubChem C5H11NO2S, CID: 6137]; Alanine (Ala) [PubChem C3H7NO2, CID: 5950]; Arginine (Arg) [PubChem C6H14N4O2, CID: 6322]; Valine (Val) [PubChem C5H11NO2, CID: 6287]; Leucine (Leu) [PubChem C6H13N02, CID: 6106]; Aspartic acid (Asp) [PubChem C4H7NO4, CID: 5960]; Threonine (Thr) [PubChem C4H9N03, CID: 6288]; Tryptophan (Trp) [PubChem C11H12N2O2, CID: 6305]; Isoleucine (Ile) [PubChem C6H13NO2, CID: 791]; Phenylalanine (Phe) [PubChem C9H11NO2, CID: 6925665]; Histidine (His) 
[PubChem C6H9N3O2, CID: 6274]; Tyrosine (Tyr) [PubChem C9H11NO3, CID: 6057]; Cystine (Cys) [PubChem C6H12N2O4S2, CID: 67678]; Serine (Ser) [PubChem C3H7NO3, CID: 5951]; Glycine (Gly) [PubChem C2H5NO2, CID: 750]; Proline (Pro) [PubChem C5H9NO2, CID: 145742].

\section{PubChem CID}

PubChem is a database of chemical molecules and their activities against biological assays. The system is maintained by the National Centre for Biotechnology Information (NCBI), a component of the National Library of Medicine, which is part of the United States National Institute of Health (NIH). Hence we can talk of PubChem Compound ID (CID).

The concentration of amino acids of Kilishi (dry weight) sample in $\mathrm{g} 100 \mathrm{~g}^{-1}$ is shown in Table 1. In the amino acids (AAs) investigated, glutamic acid (Glu) was the most concentrated with a value

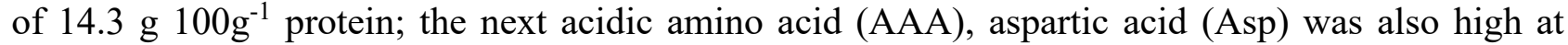

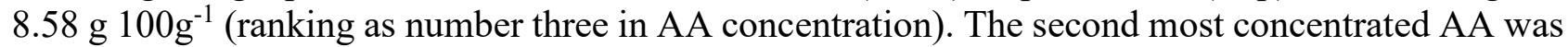

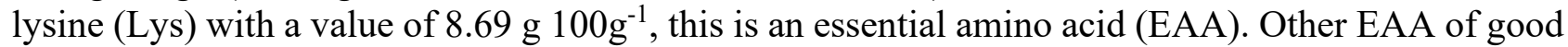
concentration were Val, Ile, Leu, Met, His and Trp whereas other nonessential amino acid (NEAA) of good concentration were Gly, Ala, Arg and Cys. The Glu value in this report was lower than the following literature values: heterosexual flesh of Neopetrolisthes maculatus $\left(17.7-17.8 \mathrm{~g} 100 \mathrm{~g}^{-1}\right.$ protein) [21]; also the Asp level was lower than the flesh of the heterosexual N. maculatus with values

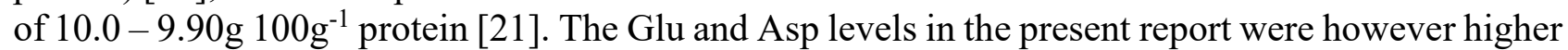
than those observed in the flesh of female West African fresh water crab (Sadananautes africanus africanus) with Glu of $130.2 \mathrm{mg} \mathrm{g}^{-1}$ protein and Asp of $72.5 \mathrm{mg} \mathrm{g}^{-1}$ protein [22]. Studies of Sinclair et al. [23], Schweigert and Payne [24], Mahan and Shields [25] showed EAAs in g $100 \mathrm{~g}^{-1}$ : Lys in beef (8.2), lamb (7.5) and pork (7.9), all lower than present report; present Leu value was 7.68 close to their own values of beef (8.5), lamb (7.2) and pork (7.6); Ile was lower at 4.08 compared to their values of beef (5.0), lamb (4.7) and pork (4.8). These EAA values were higher in the literature values

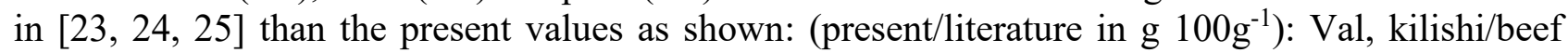
(4.41/5.6), kilishi/lamb (4.41/5.1), kilishi/pork (4.41/5.2); Thr, kilishi/beef (3.63/4.2), kilishi/lamb (3.63/4.8), kilishi/pork (3.63/5.2); Met, kilishi/beef (2.42/2.2), kilishi/lamb (2.42/2.4), kilishi/pork (2.42/2.6); Phe, kilishi/beef (3.91/4.1), kilishi/lamb (3.91/3.8), kilishi/pork (3.91/4.3); His, kilishi/beef (2.40/2.8), kilishi/lamb (2.40/2.9), kilishi/pork (2.40/3.1); Trp, kilishi/beef (1.02/1.3), kilishi/lamb (1.02/1.2), kilishi/pork (1.02/1.5). Reports of Beach et al. [26] showed the percentage values of amino acids in beef, lamb and pork: Lys, beef (8.11), lamb (8.68), pork (8.65), all lower than the present Lys (8.69) and His, beef (2.25), lamb (2.37), pork (2.16), all lower than the present His (2.40). In general, Beach et al. [26] observed that muscle tissues of these different classes of animals do not differ widely in their amino acid patterns which implies that the same amino acid composition of muscle proteins is reported throughout the animal kingdom and indicates that, as far as these amino acids are concerned, the protein of one muscle is as good as that of another in supplying amino acids in the diet.

Values of the amino acids shown in Table 1 were subjected to a combined descriptive and inferential statistics as shown in Table 2 . The amino acid values were grouped into essential and nonessential amino acids giving a set of nine members each. The mean values were close

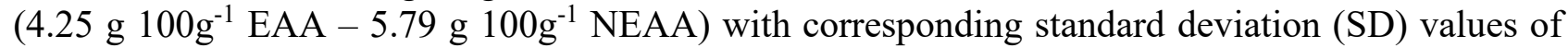
$2.48-3.81$ and coefficient of variation $(\mathrm{CV} \%)$ values of $58.4-65.9$. Note that the total EAA value

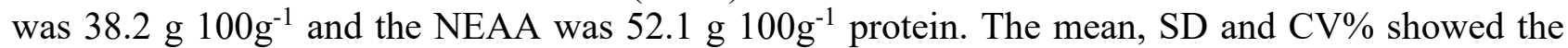
homogenous nature or otherwise of the EAA and NEAA of the kilishi sample. For the inferential statistics, these values were low: correlation coefficient $\left(r_{x y}\right)(0.1549)$, variance $\left(r_{x y}{ }^{2}\right)(0.0240)$ and regression coefficient (Rxy) (0.2381). The $r_{x y}$ was not significantly different since the critical value of 0.798 at $r_{=0.01}>r_{c}$ of 0.1549 . On the other hand the coefficient of alienation $\left(\mathrm{C}_{\mathrm{A}}\right)$ was high at 0.9879 with correspondingly low index of forecasting efficiency (IFE) of 0.0121 . The value of $C_{A}$ showed that virtually no relationship existed between the kilishi EAA and NEAA since the error of prediction of relationship was high at $98.79 \%$ whereas reduction of error of prediction of relationship was just $1.21 \%$. 
In Table 3, we depicted the summary of the concentrations of essential, aromatic, nonessential, neutral etc. of the amino acid levels in the sample in $\mathrm{g} 100 \mathrm{~g}^{-1}$. The total AAs values of

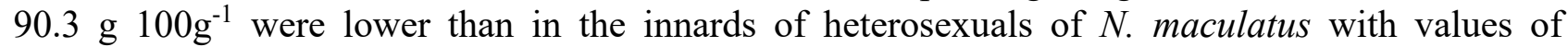

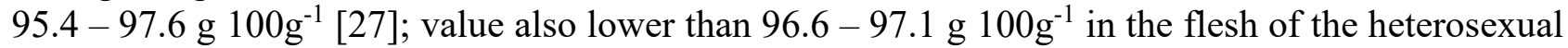
N. maculatus [21] but higher than the total AAs in the flesh of $S$. africanus africanus $\left(777.0 \mathrm{mg} \mathrm{g}^{-1}\right.$ protein) [22]. Columns in Table 3 included AAs class and other quality parameters. Total NEAA (TNEAA) was 52.1 with corresponding percentage value of 57.7. Total EAA (TEAA) was 38.2 (with His) and percentage value of 42.3 whereas values of TEAA without His was 35.8 and the corresponding percentage value was 39.7 .

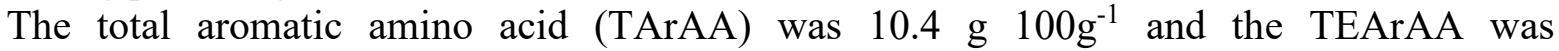

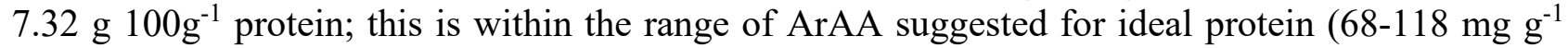
protein) [13]; this makes kilishi to be a good source of ArAA and might also be qualified as a

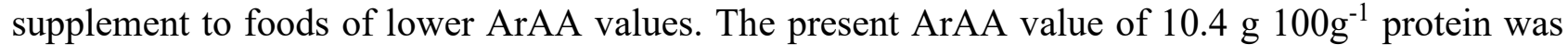

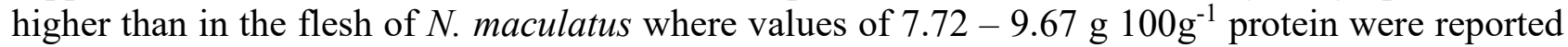
[21]. The percentage ratio of TEAA to the TAA of the sample was 42.3 ; this is above $39 \%$ considered adequate as ideal food for infants, $26 \%$ for children and $11 \%$ for adults [13]. The TEAA/TAA in egg

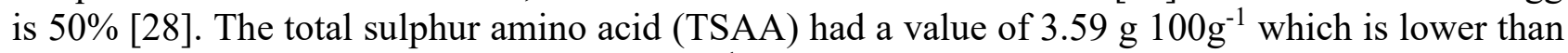
the TSAA recommended for infants $\left(58 \mathrm{mg} \mathrm{g}^{-1}\right.$ protein) [13].

The total SAA (TSAA) in the sample were made up of Met + Cys. Whereas the TSAA was

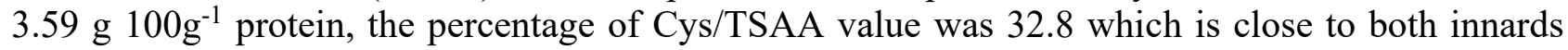
(26.7 - 33.0) and meat of $N$. maculatus at $31.9-33.1$ [27, 13]. The present \%Cys/TSAA (32.8) had close relationships with other animal protein amino acids: $27.3-32.8 \%$ in $S$. africanus africanus [22], 36.3\% in Macrotermes bellicosus [29]; 25.6\% in Zonocerus variegatus [30]; 35.5 in Archachatina marginata marginata, $38.8 \%$ in A. archatina and $21.0 \%$ in Limicolaria sp. (the last three are land snails consumed in Nigeria [31]. The percentage of Cys in TSAA in the diet of rat chick and pig is $50 \%$ [18] but the standard value is unknown to man [13]. All the examples above came from animal sources. It is noted however that vegetable protein (e.g. coconut endosperm) has a percentage Cys/TSAA of $62.8 \%$ [32]. Also reported was the high percentage of Cys/TSAA in Anacardium occidentale with a value of $50.51 \%$ [33]. From these literature values compared with the present result, it is obvious that kilishi AAs behaved like typical animal in their \%Cys/TSAA ratios. The presence of cystine and cysteine in the diet reduces the needs for Met and since all the sulphur in the diet is derived from these three AAs, the sulphur content is sometimes used as an approximate assessment of the adequacy of protein [34]. In the present result, the values for Met and Cys were (g $100 \mathrm{~g}^{-1}$ protein) 2.42 and 1.18 respectively.

The predicted protein efficiency ratio (P-PER) was calculated in three forms - P-PER 1, 2 and 3. The in-vivo P-PER is of the order of 2.2 [35]. The P-PER values as calculated were:

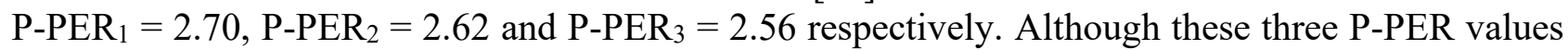
were each higher than the in-vivo value, all were lower than the following literature values: $N$. maculatus meat where values of P-PER 1 were 3.39 - 3.69 and P-PER 2 were $3.82-4.14$ [21] and also lower than the report for the innards of $N$. maculatus heterosexuals with values of P-PER 1 (2.83 - 3.01) and P-PER 2 (2.89 - 2.96) [27]. According to Friedman's [36] classification, the PER is poor $(<1.5)$, moderate $(1.5-2.0)$ and superior $(>2.0)$. On this classification, P-PERs $1,2,3$ were all in the group of superior category. Other literature P-PER values are: meat of female $S$. africanus

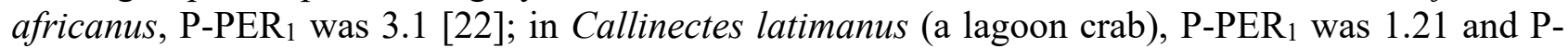
$\mathrm{PER}_{2}$ was 1.39 [37]. The present P-PER values indicated that kilishi meat might be a more physiologically utilized protein source. In general, it has been discovered that the better the protein, the lower the level in the diet that is required to produce the highest protein efficiency ratio. This emphasizes a clear reflection of the importance of the proper nutritive balance of all amino acids to produce optimum metabolic efficiency. More in Table 3, Leu/Ile ratio was 1.88, Leu - Ile (difference)

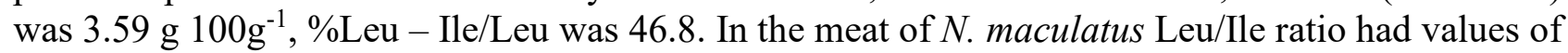
$1.60-1.63$ [21], in meat of $S$. africanus africanus, the ratio was 1.60 [22] and the innards of $N$. maculatus heterosexual the ratios were $1.54-1.91$ with difference levels of $2.87-3.97{\mathrm{~g} 100 \mathrm{~g}^{-1}}^{-1}$ 
protein and \% (Leu - Ile)/Leu values of $35.1-47.7$ [27]. From literature, the most ideal Leu/Ile is 2.36 [18]. The value of 1.88 was low to 2.36 , hence we might not experience concentration antagonism in the sample when consumed as protein source in food. It has been suggested that an amino acid imbalance from excess Leu might be a factor in the development of pellagra [38]. A high Leu imbalance in the diet impairs the metabolism of Trp and niacin, and is responsible for the niacin deficiency in sorghum eaters [39]. Experiments in dogs have shown that animals fed sorghum proteins

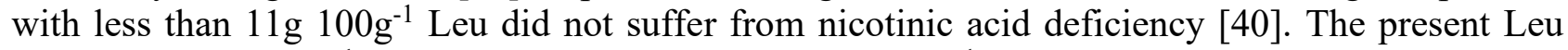

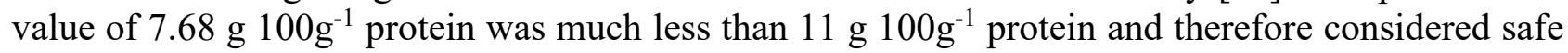
and could be beneficially exploited to prevent pellagra in endemic areas [41].

The essential amino acid index (EAAI) calculated were reported in two different forms of $\mathrm{EAAI}_{1}$ and $\mathrm{EAAI}_{2}$. In the $\mathrm{EAAI}_{1}$, the value was 1.23 . The $\mathrm{EAAI}_{1}$ under this mode has soybean as its standard for comparison. The value of EAAI in defatted soybean flour is 1.26 [24] and that for whole hen's egg is 1.55. In the amino acid composition of two fancy meats (liver and heart) of African giant pouch rat (Cricetomys gambianus), the EAAI ranged from 1.20 - 1.31 [43]. It should be noted that the absence of Trp in EAAI calculation of this mode may bear no significance in the EAAI; for example EAAI without Trp in soy flour remained 1.26 whilst it reduced to 1.54 in the whole hen's egg, i.e. a reduction of 0.01 or $0.645 \%$. For the $\mathrm{EAAI}_{2}$, value was 94.5 with its corresponding biological value (BV) of 91.3 depicting the quality of the kilishi protein. In comparison, some literature values of EAAI and BV are as follows [10]: milk, cow (whole, nonfat, evaporated or dry), EAAI (88) and BV (84, predicted; 90, observed); human, EAAI (87) and BV (83); eggs, chicken (whole, raw or dried, EAAI (100), BV (97, predicted; 96, observed); whites (raw or dried), EAAI (95), BV (92, predicted; 93, observed); yolks (raw or dried, EAAI (93), BV (89, predicted); shellfish (shrimp, including prawns, raw or canned), EAAI (67), BV (61, predicted); also 86.9 - 89.9 (EAAI) and $83.0-86.3(\mathrm{BV})$ in meat of $N$. maculatus [21] and $88.7-89.2$ (EAAI) and $85.0-85.5(\mathrm{BV})$ in innards of $N$. maculatus [27]. These literature results show the quality position of kilishi protein. EAAI is useful as a rapid tool in the evaluation of food formulation for protein quality. The isoelectric point, $p I$, was 5.63 showing the sample to be in the acidic medium of the $\mathrm{pH}$ range. The $p I$ calculation from amino acids would assist in the quick production of certain protein isolate of an organic product without evaluating the protein solubilty before getting at the $p I$.

Table 3 also contained the Lys/Trp (L/T), Met/Trp (M/T) and Phe/Tyr ratios of the sample. According to Albanese [44], in infants protein requirements, a growth pattern of amino acid requirements was obtained by assigning value of unity to the Trp need. Similar calculation of the amino acid content of mammalian tissue showed that there exists good agreement of growth needs and tissue amino acid patterns. This agreement is said to be good for the $\mathrm{L} / \mathrm{T}$ and $\mathrm{M} / \mathrm{T}$ ratios of muscle proteins which constitute approximately $75 \%$ of the infant body proteins. The present result had $\mathrm{L} / \mathrm{T}$ value of 8.55 and $\mathrm{M} / \mathrm{T}$ value of 2.38 . The $\mathrm{L} / \mathrm{T}$ value was much more than those of innards of $N$. maculatus as $3.00-5.01$ and meat as $3.31-4.27$ and also higher than $\mathrm{M} / \mathrm{T}$ values as: innards, $1.78-3.50$ and meat, $1.97-2.64[21,27]$.

Mammalian tissue patterns have the following values: L/T: muscle (6.3), viscera (5.3), plasma proteins (6.2). M/T: muscle (2.5), viscera (2.0), plasma proteins (1.1) [45]. The available evidence indicates that the utilization of dietary proteins increases as their Lys and Trp approaches that of muscle tissues. In the present study, the kilishi protein L/T value was 8.55 and it is $26.3 \%$ greater than the muscle standard of $6.3 \mathrm{~L} / \mathrm{T}$, it is also much greater than 5.3 (viscera) and 6.2 (plasma) proteins. Also the $\mathrm{M} / \mathrm{T}$ value of the present work was 2.38 which is slightly lower than the muscle standard $\mathrm{M} / \mathrm{T}$ value of 2.5 but higher than 2.0 (viscera), 1.1 (plasma) proteins. The $\mathrm{L} / \mathrm{T}$ and $\mathrm{M} / \mathrm{T}$ values were better than our observation for $N$. maculatus innards and meat [21, 27]. The mean minimum Phe requirement estimate in the presence of an excess of Tyr is $9.1 \mathrm{mg} \mathrm{kg}^{-1} \mathrm{day}^{-1}$. Hence Tyr can spare $78 \%$ of the dietary Phe need. Also the optimal proportions of dietary Phe and Tyr have been shown to be $60: 40$ respectively [46]. The Phe/Tyr in this result was low as shown in Table 3 which did not meet the optimal proportion of dietary Phe and Tyr of 60: 40 respectively.

In Table 4 we have the amino acid groups divided into classes [15]. The concentration trend of the classes follows as shown in $\mathrm{g} 100 \mathrm{~g}^{-1}$ protien: class $\mathrm{I}(27.3)>$ class $\mathrm{IV}(22.9)>$ class $\mathrm{V}(17.1)>$ 
class VI (10.4) > class II (7.27) > class VII (4.23) > class III (3.59). In the innards of N. maculatus the trend changed between classes VII and III as shown: class I $>$ class IV $>$ class V $>$ class VI $>$ class II $>$ class III > class VII [27]; this was also the trend in the meat of N. maculatus [21]. Further observation would show that the percentage were close to their individual values wih very slight differences; examples were: value (percentage): class I, 27.3 (30.2); class II, 7.27 (8.04); class III, 3.59 (3.98); class IV, 22.9 (25.3); class V, 17.1 (18.9); class VI, 10.4 (11.5); class VII, 4.23 (4.69).

In Table 5, we presented the total amino acid scores based on whole hen's egg amino acids profile and the Protein Digestibility Corrected Amino Acid Score (PDCAAS). Under whole hen's egg score comparison, the following amino acids had scores of 1.00 or $>1.00$ : Lys, His, Gly, Pro, Ala and Glu. Under PDCAAS comparison, values $>1.00$ were recorded only in Lys, Gly and Glu; this is $50 \%$ of such values observed in the egg score comparison. Ser was the limiting amino acid (LAA) in both comparisons with values of 0.461 (on egg score) and 0.388 (on PDCAAS comparison). Ser was also limiting with values of 0.511 (male) and 0.487 (female) in the innards of $N$. maculatus and in meat of $N$. maculatus Ser values of 0.513 (male) and 0.516 (female), all on egg score comparisons $[21,27]$. To correct the present LAA scores to expected normal level in order to fulfil the day's needs for all the amino acids in kilishi sample, 100/46.1 and (or) 100/38.8; i.e. 2.17 and (or) 2.58 times as much kilishi protein would have to be consumed (eaten) when it serves as the sole protein source in the diet as the case may be. The descriptive statistics in Table 5 showed that the $\mathrm{CV} \%$ ranged between $11.9-12.3$. However, in this CV\% values, out of 19 values reported, $15 / 19$ or $78.9 \%$ had values of $12.2 \% ; 2 / 19$ or $10.5 \%$ had values of $12.3 ; 1 / 19$ was for 12.1 and 11.9 in each case giving a value of $5.26 \%$. Generally speaking, one could reasonably conclude that egg score and PDCAAS comparison had variations of $12.2 \%$. In Table 6 , we have EAA scores of kilishi based on FAO/WHO [12] standards. Also there are the PDCAAS scores. For the FAO/WHO [12] scores, these acids had scores $>1.00$ : Lys, Met + Cys, Ile, Leu, Phe + Tyr, Trp and total EAA whereas in PDCAAS, only Lys and total EAA had score values $>1.00$. Val was the LAA in both comparison scores with values of 0.882 and 0.742 respectively for provisional EAA scores and the PDCAAS. Correction values would therefore be $100 / 88.2$ or 1.13 x protein value and $100 / 74.2$ or 1.35 x protein value for full protein availability for body metabolism. In the CV\%, $6 / 9$ or $66.7 \%$ had values of $12.2 \% ; 1 / 9$ or $11.1 \%$ each for CV\% 12.0, 12.1 and 12.3. In Table 7, we have depicted the EAA scores of kilishi based on requirements or pre-school child $(2-5 \mathrm{y})$. In the pre-school requirement score comparison only Trp had score $<1.00$ and hence LAA with a value of 0.927 . Correction value here was $1.08 \mathrm{x}$ protein of kilishi. For PDCAAS, score values $>1.00$ were in Lys, Met + Cys, Val, Ile, His and total EAA. Also here Trp was the LAA with a value of 0.780 , hence correction was $1.28 \times$ kilishi protein to get balanced protein source. Here, among the CV\% values $6 / 10(60.0 \%)$ were $12.2 \% ; 3 / 10(30.0 \%)$ were with 12.3 and $1 / 10$ or $10.0 \%$ was for $12.1 \%$. Protein Digestibility Corrected Amino Acid Score (PDCAAS) is a method of evaluating the protein quality, with a maximum possible score of 1.0. Most animal meats like beef have a score of approximately 0.9 , compared to values of $0.5-0.7$ for most plant foods [47].

The results of the scores from the egg/PDCAAS, provisional scoring pattern/PDCAAS and pre-school child requirement/PDCAAS from Tables 5, 6, 7 were subjected to statistical analyses as depicted in Table 8. In all the comparisons, all $r_{x y}$ values were high and positively significant. These values were also high: $\mathrm{r}_{\mathrm{xy}}{ }^{2}$, Rxy and IFE. Since all the IFE values were high at $0.9925-0.9962$, it meant that the quality criteria as depicted in the various scores from the standard score comparisons and the PDCAAS values could be used to ascertain the kilishi quality at virtually similar levels.

In Table 9, we have estimates of amino acid requirements at ages $10-12$ years in $\mathrm{mg} \mathrm{kg}^{-1}$ day $^{-1}$ at the body weight of $30 \mathrm{~kg}$. The protein of the kilishi sample had values greater than the estimates in all the amino acids to the tune of between $74.9-453 \%$. Among the four principal limiting amino acids of Lys (first), Met + Cys (second), Thr (third) and Trp (fourth), the percentage kilishi protein excess values were: Lys (211\%), Met + Cys (185\%), Thr (123\%) and Trp (448\%).

The various amino acids have different types of functions in the human body, phenylalanine, a precursor for neurotransmitters which helps in the production of other amino acids and their functioning. Valine helps in stimulating muscle growth, regeneration and it produces energy. 
Threonine is a principal component of structural proteins such as collagen and elastin which are present in skin and connective tissues, helps in fat metabolism and immune function. Tryptophan is a precursor to serotonin, a neurotransmitter that helps in appetite, sleep and mood regulation. Methionine plays a major role in metabolism, detoxification, helps in tissue growth and in the absorption of minerals such as zinc and selenium needed by the body. Leucine helps in regulating blood sugar levels, enhances wound healing and stimulates growth hormones. Isoleucine helps in muscle metabolism, immune function, haemoglobin production and energy regulation. Branchedchain amino acids are Val, Leu and Ile. Lysine helps in protein synthesis, calcium absorption, immune function, energy production, hormone production and in collagen production. Histidine, a neurotransmitter helps maintaining the protective barrier called myelin sheath that surrounds the nerve cells, helps in digestion, immune response, sleep - wake cycles and sexual functions [48].

\section{Conclusions}

Kilishi (Nigerian Beef Jerky) meat will serve as a good source of animal protein as well as

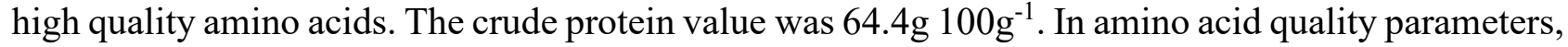
P-PER was in the superior group of value ( $>2.0)$, both EAAI, BV and protein digestibility were high; both Lys/Trp and Met/Trp were high. Scores at standard forms and PDCAAS were highly comparable with slight variation of mostly $12.2 \%$. Estimates of amino acid requirements at ages $10-12$ years $\left(\mathrm{mg} \mathrm{kg}^{-1} \mathrm{day}^{-1}\right)$ in kilishi were all higher than the standards by a range of $74.9-453 \%$. Based on the above, kilishi will serve as a healthy snack with a lot of health benefits; it is protein-filled and retains its nutritious value despite being dried.

Table 1. Amino acid profile (g $100 \mathrm{~g}^{-1}$ protein) of Nigerian meat jerky (kilishi)

\begin{tabular}{|l|c|c|}
\hline Amino acid & CID $^{\dagger}$ & Kilishi \\
\hline Valine (Val)* & 6287 & 4.41 \\
\hline Threonine (Thr)* & 6288 & 3.63 \\
\hline Isoleucine (Ile)* & 791 & 4.08 \\
\hline Leucine (Leu)* & 6106 & 7.68 \\
\hline Lysine (Lys)* & 5962 & 8.69 \\
\hline Methionine (Met)* & 6137 & 2.42 \\
\hline Phenylalanine (Phe)* & 6925665 & 3.91 \\
\hline Histidine (His)* & 6274 & 2.40 \\
\hline Tryptophan (Trp)* & 6305 & 1.02 \\
\hline Glycine (Gly) & 750 & 5.40 \\
\hline Alanine (Ala) & 5950 & 5.70 \\
\hline Serine (Ser) & 5951 & 3.64 \\
\hline Proline (Pro) & 145742 & 4.23 \\
\hline Aspartic acid (Asp) & 5960 & 8.58 \\
\hline Glutamic acid (Glu) & 33032 & 14.3 \\
\hline Arginine (Arg) & 6322 & 6.02 \\
\hline Tyrosine (Tyr) & 6057 & 3.04 \\
\hline Cystine (Cys) & 67678 & 1.18 \\
\hline
\end{tabular}

$*$ Essential amino acid. Determination were done in duplicate and dry weight. $\uparrow \mathrm{CID}=$ Compound ID. 
Table 2. Statistical analysis of the data from Table 1 pertaining to the amino acid profile of essential and non-essential amino acid of kilishi

\begin{tabular}{|c|c|c|c|}
\hline Statistics & $\begin{array}{c}\text { Essential } \\
\text { amino acid }\end{array}$ & & $\begin{array}{c}\text { Non-essential } \\
\text { amino acid }\end{array}$ \\
\hline Total amino acid value & 38.2 & & 52.1 \\
\hline Mean & 4.25 & & 5.79 \\
\hline Standard deviation (SD) & 2.48 & & 3.81 \\
\hline Coefficient of variation $(\mathrm{CV} \%)$ & 58.4 & & 65.9 \\
\hline Correlation coefficient $\left(\mathrm{r}_{\mathrm{xy}}\right)$ & & 0.1549 & \\
\hline Variance $\left(\mathrm{r}_{\mathrm{xy}}^{2}\right)$ & & 0.0240 & \\
\hline Regression coefficient $(\mathrm{Rxy})$ & & 0.2381 & \\
\hline Coefficient of alienation $\left(\mathrm{C}_{\mathrm{A}}\right)$ & & 0.9879 & \\
\hline Index of forecasting efficiency (IFE) & & 0.0121 & \\
\hline Remark & & $\begin{array}{c}\text { Results not } \\
\text { significantly } \\
\text { different }\end{array}$ & \\
\hline
\end{tabular}

Table 3. Composition in terms of different classes of amino acids in kilishi sample (g $100 \mathrm{~g}^{-1}$ protein)

\begin{tabular}{|c|c|}
\hline Parameter & Kiishi \\
\hline Total amino acid (TAA) & 90.3 \\
\hline Total non-essential acid (TNEAA) & 52.1 \\
\hline$\%$ TNEAA & 57.7 \\
\hline \multicolumn{2}{|l|}{ Total essential amino acid (TEAA) } \\
\hline With His & 38.2 \\
\hline Without His & 35.8 \\
\hline \multicolumn{2}{|l|}{$\%$ TEAA } \\
\hline With His & 42.3 \\
\hline Without His & 39.7 \\
\hline Total aliphatic amino acid (TAIAA) (CLASS I) & 27.3 \\
\hline$\%$ TAIAA & 30.2 \\
\hline Total essential aliphatic amino acid (TEAIAA) & 16.2 \\
\hline \%TEAIAA & 17.9 \\
\hline Total aromatic amino acid (TArAA) (CLASS VI) & 10.4 \\
\hline$\%$ TArAA & 11.5 \\
\hline Total essential aromatic amino acid (TEArAA) & 7.32 \\
\hline$\%$ TEArAA & 8.11 \\
\hline Total acidic amino acid (TAAA) (CLASS IV) & 22.9 \\
\hline$\%$ TAAA & 25.3 \\
\hline Total basic amino acid (TBAA) (CLASS V) & 17.1 \\
\hline$\%$ TBAA & 18.9 \\
\hline Total neutral amino acid (TNAA) & 49.3 \\
\hline$\%$ TNAA & 54.6 \\
\hline Total hydroxyl amino acid (THAA) (CLASS II) & 7.27 \\
\hline$\%$ THAA & 8.04 \\
\hline Cyclic amino acid (Pro) (CAA) (CLASS VII) & 4.23 \\
\hline$\%$ CAA & 4.69 \\
\hline Total sulphur amino acids (TSAA) (CLASS III) & 3.59 \\
\hline
\end{tabular}




\begin{tabular}{|c|c|}
\hline$\%$ TSAA & 3.98 \\
\hline$\%$ Cys in TSAA & 32.8 \\
\hline Leu/Ile ratio & 1.88 \\
\hline (Leu-Ile) difference & 3.59 \\
\hline$\%$ (Leu- Ile)/Leu & 46.8 \\
\hline$\%$ (Leu- Ile)/total amino acid profile & 3.98 \\
\hline P-PER 1 ,i.e. $-0.468+0.454$ (Leu)-0.105 (Tyr) & 2.70 \\
\hline 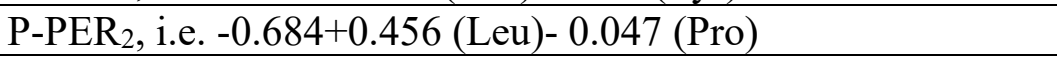 & 2.62 \\
\hline $\begin{array}{l}\text { P-PER } 3 \text {, i.e. }-1.816+0.435 \times \text { Met }+0.78 \times \text { Leu }+0.211 \times \text { His }- \\
0.944 \times \text { Tyr }\end{array}$ & 2.52 \\
\hline Calculated isoelectric point $(p I)$ & 5.63 \\
\hline Essential amino acid index: EAAI ${ }_{1}$ & 1.23 \\
\hline $\mathrm{EAAI}_{2}$ & 94.5 \\
\hline Biological value (BV) & 91.3 \\
\hline Lys/Trp or L/T & 8.55 \\
\hline Met/Trp or M/T & 2.38 \\
\hline Phe/Tyr & 1.29 \\
\hline Protein digestibility & $84.1 \%$ \\
\hline
\end{tabular}

Table 4. Amino acid groups of kilishi

\begin{tabular}{|c|c|c|}
\hline Class & $\begin{array}{c}\text { Value in }{\mathrm{g} 100 \mathrm{~g}^{-1}}_{\text {protein }} \\
\text { prote }\end{array}$ & Percentage value \\
\hline $\begin{array}{l}\text { I. [with aliphatic side chains (hydrogen and } \\
\text { carbon)= Gly, Ala, Val, Leu, Ile] }\end{array}$ & 27.3 & 30.2 \\
\hline $\begin{array}{l}\text { II. [with side chains containing hydroxylic } \\
(\mathrm{OH}) \text { groups }=\text { Ser, Thr] }\end{array}$ & 7.27 & 8.04 \\
\hline $\begin{array}{l}\text { III. [with side chains containing sulphur } \\
\text { atoms = Cys, Met] }\end{array}$ & 3.59 & 3.98 \\
\hline $\begin{array}{l}\text { IV. [with side chains containing acidic } \\
\text { groups or their amides = Asp, Glu] }\end{array}$ & 22.9 & 25.3 \\
\hline $\begin{array}{l}\text { V. [with side chains containing basic groups } \\
=\text { Arg, Lys, His] }\end{array}$ & 17.1 & 18.9 \\
\hline $\begin{array}{l}\text { VI. [containing aromatic rings }=\text { His, Phe, } \\
\text { Tyr, Trp] }\end{array}$ & 10.4 & 11.5 \\
\hline VII. [imino acids = Pro $]$ & 4.23 & 4.69 \\
\hline
\end{tabular}


Table 5. Amino acid scores of kilishi based on whole hen's egg amino acid

\begin{tabular}{|l|c|c|c|c|c|}
\hline Amino acid & Egg score & Corrected score & Mean & SD & CV\% \\
\hline Val & 0.588 & 0.495 & 0.542 & 0.066 & 12.2 \\
\hline Thr & 0.711 & 0.598 & 0.655 & 0.080 & 12.2 \\
\hline Ile & 0.729 & 0.613 & 0.671 & 0.082 & 12.2 \\
\hline Leu & 0.925 & 0.778 & 0.852 & 0.104 & 12.2 \\
\hline Lys & 1.40 & 1.18 & 1.29 & 0.156 & 12.1 \\
\hline Met & 0.756 & 0.636 & 0.696 & 0.085 & 12.2 \\
\hline Phe & 0.767 & 0.645 & 0.706 & 0.086 & 12.2 \\
\hline His & 1.00 & 0.841 & 0.921 & 0.112 & 12.2 \\
\hline Trp & 0.567 & 0.477 & 0.522 & 0.064 & 12.2 \\
\hline Gly & 1.80 & 1.52 & 1.66 & 0.198 & 11.9 \\
\hline Ala & 1.06 & 0.892 & 0.976 & 0.119 & 12.2 \\
\hline Ser & 0.461 & 0.388 & 0.425 & 0.052 & 12.2 \\
\hline Pro & 1.11 & 0.934 & 1.02 & 0.124 & 12.2 \\
\hline Asp & 0.802 & 0.674 & 0.738 & 0.091 & 12.3 \\
\hline Glu & 1.19 & 1.00 & 1.10 & 0.134 & 12.2 \\
\hline Arg & 0.987 & 0.830 & 0.909 & 0.111 & 12.2 \\
\hline Tyr & 0.760 & 0.639 & 0.700 & 0.086 & 12.2 \\
\hline Cys & 0.656 & 0.551 & 0.604 & 0.074 & 12.3 \\
\hline Total & 0.904 & 0.760 & 0.832 & 0.102 & 12.2 \\
\hline
\end{tabular}

Table 6. Essential amino acid scores of kilishi based on FAO/WHO [12] standards

\begin{tabular}{|l|c|c|c|c|c|}
\hline Amino acid & $\begin{array}{c}\text { FAO/WHO, } \\
\text { 1973 based } \\
\text { score }\end{array}$ & $\begin{array}{c}\text { Corrected } \\
\text { score }\end{array}$ & Mean & SD & CV\% \\
\hline Lys & 1.58 & 1.33 & 1.46 & 0.177 & 12.1 \\
\hline Thr & 0.908 & 0.763 & 0.836 & 0.103 & 12.3 \\
\hline Met + Cys & 1.03 & 0.866 & 0.948 & 0.116 & 12.2 \\
\hline Val & 0.882 & 0.742 & 0.812 & 0.099 & 12.2 \\
\hline Ile & 1.02 & 0.858 & 0.939 & 0.115 & 12.2 \\
\hline Leu & 1.10 & 0.925 & 1.01 & 0.124 & 12.2 \\
\hline Phe + Tyr & 1.16 & 0.976 & 1.07 & 0.130 & 12.2 \\
\hline Trp & 1.02 & 0.858 & 0.939 & 0.115 & 12.2 \\
\hline Total & 1.28 & 1.08 & 1.18 & 0.141 & 12.0 \\
\hline
\end{tabular}


Table 7. Essential amino acid scores of based on requirements of pre-school child (2-5years) standards [13]

\begin{tabular}{|l|c|c|c|c|c|}
\hline Amino acid & $\begin{array}{c}\text { Pre-school } \\
\text { child } \\
\text { requirement } \\
\text { based score }\end{array}$ & $\begin{array}{c}\text { Corrected } \\
\text { score }\end{array}$ & Mean & SD & CV\% \\
\hline Lys & 1.50 & 1.26 & 1.38 & 0.170 & 12.3 \\
\hline Thr & 1.07 & 0.900 & 0.985 & 0.120 & 12.2 \\
\hline Met + Cys & 1.44 & 1.21 & 1.33 & 0.163 & 12.3 \\
\hline Val & 1.26 & 1.06 & 1.16 & 0.141 & 12.2 \\
\hline Ile & 1.46 & 1.23 & 1.35 & 0.163 & 12.1 \\
\hline Leu & 1.16 & 0.976 & 1.07 & 0.130 & 12.2 \\
\hline Phe + Tyr & 1.10 & 0.925 & 1.01 & 0.124 & 12.2 \\
\hline Trp & 0.927 & 0.780 & 0.854 & 0.104 & 12.2 \\
\hline His & 1.26 & 1.06 & 1.16 & 0.141 & 12.2 \\
\hline Total & 1.43 & 1.20 & 1.32 & 0.163 & 12.3 \\
\hline
\end{tabular}

Table 8. Summary of the statistical analyses of the scores reported in Tables 5, 6 and 7

\begin{tabular}{|l|c|c|c|}
\hline Statistics & $\begin{array}{c}\text { Egg scores versus } \\
\text { corrected scores }\end{array}$ & $\begin{array}{c}\text { Provisional scoring } \\
\text { pattern versus } \\
\text { corrected scores }\end{array}$ & $\begin{array}{c}\text { Pre-school child } \\
\text { requirement versus } \\
\text { corrected scores }\end{array}$ \\
\hline $\mathrm{r}_{\mathrm{xy}}$ & 0.99999 & 0.99999 & 0.99997 \\
\hline $\mathrm{r}_{\mathrm{xy}}{ }^{2}$ & 0.99998 & 0.99997 & 0.99994 \\
\hline $\mathrm{Rxy}$ & 0.8447 & 0.8444 & 0.8388 \\
\hline $\mathrm{Mean} 1$ & 0.9038 & 1.11 & 1.26 \\
\hline $\mathrm{SD}_{1}$ & 0.3184 & 0.2144 & 0.1948 \\
\hline $\mathrm{CV} \% 1$ & 35.2 & 19.3 & 15.5 \\
\hline $\mathrm{Mean} 2$ & 0.7606 & 0.9331 & 0.1634 \\
\hline $\mathrm{SD} 2$ & 0.2689 & 0.1811 & 15.4 \\
\hline $\mathrm{CV} \% 2$ & 35.4 & 19.4 & 0.0075 \\
\hline $\mathrm{C}_{\mathrm{A}}$ & 0.0038 & 0.0054 & 0.9925 \\
\hline $\mathrm{IFE}$ & 0.9962 & 0.9946 & Significantly different \\
\hline $\mathrm{Remark}$ & Significantly different & Significantly different & . \\
\hline
\end{tabular}

Egg score is significantly different at $n-2[n-2=19-2=17(\mathrm{df})]$ and $\mathrm{r}=0.01$ (critical value $=0.575$ ); provisional score is significantly different at $\mathrm{n}-2[\mathrm{n}-2=9-2=7(\mathrm{df})]$ and $\mathrm{r}=0.01$ (critical value $=0.798$ ); pre-school child score is significantly different at $\mathrm{n}-2[\mathrm{n}-2=10-2=8(\mathrm{df})]$ and $\mathrm{r}=0.01$ (critical value $=0.765)$. 
Table 9. Estimates of amino acid requirements at ages 10-12 years $\left(\mathrm{mg} \mathrm{kg}^{-1} \mathrm{day}^{-1}\right)$

\begin{tabular}{|l|c|c|c|c|c|}
\hline Amino acid & $\begin{array}{c}\text { School } \\
\text { boys } \\
\mathbf{1 0 - 1 2 y} \\
\mathbf{=} \mathbf{R}\end{array}$ & $\begin{array}{c}\text { School boys } \\
\mathbf{3 0 k g} \mathbf{x} \mathbf{R} \\
\mathbf{S}\end{array}$ & $\begin{array}{c}\text { Kilishi } \\
\text { equivalent } \\
\mathbf{T}\end{array}$ & $\begin{array}{c}\text { Difference } \\
\text { (S-T) }\end{array}$ & $\begin{array}{c}\text { Percentage } \\
\text { difference (S-T } \\
\text { \%) }\end{array}$ \\
\hline Ile & 30 & 900 & 2628 & -1728 & -192 \\
\hline Leu & 45 & 1350 & 4946 & -3596 & -266 \\
\hline Lys & 60 & 1800 & 5596 & -3796 & -211 \\
\hline Met+Cys & 27 & 810 & 2312 & -1502 & -185 \\
\hline Phe+Tyr & 27 & 810 & 4476 & -3666 & -453 \\
\hline Thr & 35 & 1050 & 2338 & -1288 & -123 \\
\hline Trp & 4 & 120 & 657 & -537 & -448 \\
\hline Val & 33 & 990 & 2840 & -1850 & -187 \\
\hline Total EAAs & 261 & 7830 & 31215 & -23385 & -74.9 \\
\hline
\end{tabular}

- T > S; T was calculated as: specific amino acid x $10 \mathrm{x}$ appropriate corresponding protein value.

\section{References}

[1] E. C. Igwe, A. Nura, N. Abusalam, M. Dandago, J. E. Obiegbuna. Evaluation of production techniques and quality assessment of kilishi in some parts of Kano, Kano state, Nigeria, Int. J. Basic Sci. Tech. 1 (2015)35-38

[2] Using Kilishi - Nigerian meat jerky as a healthy snack for weight loss. Nigerian meat jerky as a healthy snack for weight loss. Available: https:// www.africanweightloss.com>...

[3] Special Report, Nigeria's meat of possibilities (video documentary) - Nigeria Today. 30 April, 2016.

[4] Nigeria, Kano - Kilishi is Everything to the People. Retrieved 7 July 2016.

[5] L. Umuoke, How to prepare Kilishi, InfoGuideNIGERIA.COM (Information Guide in Nigeria), August 27, 2018.

[6] AOAC, Official Methods of Analysis, 18th ed., Association of Official Analytical Chemists, Washington, DC, Method 982 - 30, 2006.

[7] P. O. Danka, D. T. Dobrina, V. I. Kalin, Simultaneous identification and determination of total content of amino acids in food supplements - tablets by gas chromatography, Asian J. Pharm. Clin. Res. 5(2) (2012) 57-68.

[8] O. Olaofe, E. T. Akintayo, Prediction of isoelectric point of legume and oil seed proteins from their amino acid composition, The J. Technosci. 4 (2000) 49-53.

[9] R. H. Alsmeyer, A. E. Cunningham, M. L. Happich, Equations to predict PER from amino acid analysis, Food Technol. 28 (1974) 24-38.

[10] B. L. Oser, An Integrated Essential Amino Acid Index for Predicting the Biological Value of Proteins, in: A. A. Albanese (Ed.), Protein and Amino Acid Nutrition. Academic Press, New York, 1959, pp. 281-295.

[11] A. A. Paul, D. A. T. Southgate, J. Russsel, First Supplement to McCance and Widdowson's The Composition of Foods: Amino acids, mg per 100g Food, fatty acids, g per 100g Food. HM Stationary Off, London, 1978.

[12] FAO/WHO. Energy and protein requirements, Technical Report Series No 522, WHO, Geneva, 1973. 
[13] FAO/WHO/UNU, Energy and protein requirements, Technical Report Series No 724, WHO, Geneva, 1985.

[14] F. H. Steinke, E. E. Prescher, D. T. Hopkins, Nutritional evaluation (PER) of isolated soybean protein and combinations of food proteins, Journal of Food Science 45 (1980) 323-327.

[15] D. C. Nieman, D. E. Butterworth, C. N. Nieman, Nutrition. WC Brown Publishers, Dubuque, 1992.

[16] W. R. Akeson, M. Stahmann, A pepsin pancreatic index of protein quality evaluation, Journal of Nutrition 83 (1964) $257-261$.

[17] E. G. Abimorad, G. H. Squassoni, D. J. Carneiro, Apparent digestibility of protein, energy and amino acids in some selected food ingridients for pacu Piaracious mesopotamicus, Aquacult. Nutr. 14 (2008) $374-380$.

[18] FAO/WHO, Protein quality evaluation, Report of Joint FAO/WHO Expert Consultation. Food and Nutrition Paper 51, FAO, Rome, 1991.

[19] R. A. Oloyo, Fundamentals of research methodology and applied sciences, ROA Educational Press, Ilaro, Nigeria, 2001.

[20] PubChem and the American Chemical Society, Reshaping Scholarly Communication, University of Califonia, USA, 2005-05-31. Retrieved 2018-10-15.

[21] E. I. Adeyeye, Amino acid profiles of the flesh of the heterosexual pairs of Neopetrolisthes maculatus, International Letters of Natural Sciences 61 (2017) 23-35.

[22] E. I. Adeyeye, Amino acid composition of whole body, flesh and exoskeleton of female common West African fresh water crab Sudanautes africanus africanus, Pak J. Nutr. 7 (2008) $748-752$.

[23] A. Sinclair, N. Mann, S. O'Connell, The Nutrient Composition of Australian Beef and Lamb, RMIT, Melbourne, 1999.

[24] B. S. Schweigert, B. J. Payne, A Summary of the Nutrient Content of Meat, Bulletin No. 30, American. Chicago: Meat Inst. Foundation, 1956.

[25] D. C. Mahan, R. G. Shields Jr., Essential and nonessential amino acid composition of pigs from birth to 145 kilograms of body weight, and comparison to other studies, J. of Animal Science 76(2) (1998) $513-521$.

[26] E. F. Beach, B. Munks, A. Robinson, The amino acid composition of animal tissue protein, J. Biol. Chem. 148 (1943) $431-439$.

[27] E. I. Adeyeye, Simultaneous identification and evaluation of amino acid profiles of the male and female innards of Neopetrolisthes maculatus, International Letters of Natural Sciences 75 (2019) $13-26$.

[28] FAO/WHO, Protein quality evaluation, Report of Joint FAO/WHO Consultation, Bethesda, MD, 4-8 December, 1989, FAO/WHO, Rome, 1990.

[29] E. I. Adeyeye, The composition of the winged termites, Macrotermes bellicosus, Journal of Chemical Society of Nigeria 30(2) (2005) 145-149.

[30] E. I. Adeyeye, Amino acid composition of variegated grasshopper, Zonocerus variegatus, Tropical Science 45(4) (2005) 141-143.

[31] E. I. Adeyeye, E. O. Afolabi, Amino acid composition of three different types of land snails consumed in Nigeria, Food Chemistry 85(4) (2004) 535 - 539.

[32] E. I. Adeyeye, The chemical composition of liquid and solid endosperm of ripe coconut. Oriental Journal of Chemistry 20(3) (2004) 471-476. 
[33] E. I. Adeyeye, S. S. Asaolu, A. O. Aluko, Amino acids composition of two masticatory nuts (Cola acuminata and Garcinia kola) and snack nut (Anacardium occidentale), Int. J. Food Science and Nutr. 58(4) (2007) $241-249$.

[34] S. Bingham, Dictionary of Nutrition, Barrie and Jenkins, London, 1977.

[35] H. G. Muller, G. Tobin, Nutrition and Food Processing, Avi Publishing, Westport, CT, 1980.

[36] M. Friedman, Nutritional value of proteins from different food sources - A review, Journal of Agriculture and Food Chemistry 44 (1996) 6 - 29.

[37] E. I. Adeyeye, M. A. Oyarekua, A. J. Adesina, Proximate, mineral, amino acid composition and mineral safety index of Callinectes latimanus, International Journal of Development Research 4 (2014) 2641-2649.

[38] FAO, Sorghum and millets in human nutrition, FAO Food Nutrition Series No 27, FAO/UN, Rome, 1995.

[39] B. Belavady, S. G. Srikantia, C. Gopalan, The effect of oral administration of leuane on the metabolism of tryptophan, Biochem. J. 87(1963) $652-655$.

[40] B. Belavady, P. U. Rao, Leucine and Isoleucine Content of Jowar and its Pellagragenicity, Indian Exp. Biol. 17(7) (1979) 659-661.

[41] Y. G. Deosthale, Nutrition dimension of high yielding and hybrid crop varieties: Locational and varietal differences in nutritional value, in: FAO, FAO Food and Nutrition Series No 27, Sorghum and Millets in Human Nutrition, FAO, p. 82.

[42] J. C. Cavins, D. F. Kwolek, G. E. Inglett, J. C. Cowen, Amino acid analysis of soybean meal: interlaboratory study, Journal of Association of Official Analytical Chemists, 55 (1972) 686 694.

[43] E. I. Adeyeye, M. O. Aremu, Amino acid composition of two fancy meats (Liver and Heart) of African giant pouch rat (Cricetomys gambianus), Oriental Journal of Chemistry 27(4) (2011) 1409-1419.

[44] A. A. Albanese, Protein and Amino Acid Requirements of Mammals, Academic Press, New York, 1950.

[45] H. H. Mitchell, A method for determining the biological value of protein, in: A.A. Albanese (Ed.), Protein and Amino Acid Requirements of Mammals, Academic Press, New York, 1950, pp. $1-32$.

[46] P. B. Pencharz, J. W-C Hsu, R. O. Ball, Aromatic amino acid requirements in healthy human subjects, The Journal of Nutrition (2007) $1-3$.

[47] G. Schaafma, The protein digestibility-corrected amino acid score, J. Nutr. 130 (2000) 1865S $1867 \mathrm{~S}$.

[48] B. Walther, A. Schmid, R. Sieber, K. Wehmuller, Cheese in nutrition and health, Diary Science and Technology 88(4-5) (2008) $389-405$. 